\title{
PSYCHOLOGY AMONG DIASPORA ARMENIAN SCIENTISTS
}

With over two-thirds of the world's 11 million Armenians living outside the Republic of Armenia today, how are Diaspora Armenians involved in psychological science and practice? It is notable that many Armenians are so active among the key behavioral scientists in the world today, across national borders. In this part, we will introduce 3 Diaspora Armenians, who describe their experiences and how Diaspora Armenians can more closely cooperate with colleagues in the Republic of Armenia.

Ani Kalayjian, Columbia University MeaningfulWorld: 30 years of Humanitarian Relief to Armenia \& the Globe

Harold Takooshian, Fordham University

The Armenian Behavioral Science Association: 30 years later

Shakeh Kaftarian, Armenian American Mental Health Association

The Armenian American Mental Health Association in California:

Opportunities \& challenges

\section{THE ARMENIAN BEHAVIORAL SCIENCE ASSOCIATION: ABSA, 30 YEARS LATER}

Takooshian. H. (Fordham University, New York City, USA),

takoosh@aol.com

Abstract .This three-part report details: (1) The origin of ABSA on 31 August 1987 in New York City. (2) Its mission, growth, and diverse activities since 1987. (3) Its current status and possible future in 2019.

Keywords: Armenians, behavioral science, history

1. Origins. ABSA was founded at $6 \mathrm{pm}$ on 31 August 1987, in the elegant rooftop faculty lounge of Fordham University in New York City. This historic, long-in-coming gathering was a "perfect storm" in at least 5 ways: (a) That week the annual meetings of both the American Psychological Association (APA) and International Council of Psychologists (ICP) were in Manhattan, drawing Hye psychologists from many regions. (b) ABSA founders were kindly given program time and space by APA, ICP, and Fordham (Takooshian, 1987a). (c) ABSA had in place 6 Directors representing 6 behavioral sciences: Anny P. Bakalian, sociology/anthropology), Haikaz M. Grigorian (psychiatry), Hagop S. Pambookian (psychology), Mardo Soghomian (political science), Harold Takooshian (social sciences), Richard H. Tashjian (social statistics). (d) After months of planning, the lavish ABSA reception was funded by "tomodon" Haikaz Grirorian's Diaspora Foundation, included piano and patriotic songs with Shakeh Kaftarian at the piano, and a program featuring over 30 diverse scientists like psychologist Levon Melikian (Beirut), sociologist Levon Chorbajian (Massachusetts), 
political scientist M. Hrach Zadoian (NYC), Meline Karakashian (New Jersey), Harold Goolishian (Texas). (e) The reception was videotaped by A. Vincent Toth (1987), to carry personal greetings to Yerevan colleagues that month by Harold Takooshian, who left that month for a Fulbright Award to Yerevan State University. In turn, in fall of 1987, Takooshian (1987b) videotaped a census of Yerevan psychologists, to share in 1988 with USA colleagues.

2. Growth. From its start, the mission of ABSA is clear: to develop ways to advance the work of Armenians in the behavioral sciences in the USA and globally. (a) Directories. Right after the massive earthquake on 7 December 1988, ABSA quickly published its first Directory of 304 U.S. Armenian Behavioral Scientists in 1989, flagging 30 who were available for earthquake relief. By 1995, the third ABSA Directory grew to 506 people. In addition, ABSA published two other Directories for the Republic of Armenia: 53 sociologists in 15 programs (Poghosian, Kalayjian \& Takooshian, 1991), and 167 psychologists in 38 programs (Vardanyan, Takooshian \& Karakashian, 1991). (b) Bulletins. During the 1990s, ABSA published about 15 Bulletins with news and opportunities for Armenians in the behavioral sciences. (c) Gatherings. Since 1987, ABSA has hosted over 30 regional and national networking gatherings at conventions in the USA and world-wide, such as the American Psychological Association. (d) Awards. Since 1987, ABSA has presented over 35 "Outstanding Achievement Awards" to notables who have been leaders in the behavioral sciences. In the USA, it is striking how each behavioral science has key Armenian-ancestry leaders, like Armen Alchian (economics), sociology (Berch Berberoglu), psychiatry (Hagop Akiskal), political science (R. Hrair Dekmejian). In U.S. psychology, the APA recognizes 54 specialty divisions, and over half of these have leaders of Armenian ancestry, such as teaching (Sath Arsenian), religion (Raymond F. Paloutzian), history (William S. Sahakian), industrial (Charles A Pounian), family (Harold A. Goolishian). personality (Albert Mehrabian), group therapy (Yvonne M. Agazarian), media psychology (Mary K. Alvord). (e) Research. A survey completed by 200 of these behavioral scientists found: $49 \%$ are fluent in Armenian, and this fluency significantly correlated with increased involvement in Armenian community activities $(r=+.47, p<.01)$. This survey also found that $66 \%$ were interested in volunteer efforts, $68 \%$ in paid consulting, $61 \%$ in speaking with mass media, $67 \%$ in public speaking, $84 \%$ in counseling students. About half of these are not involved in the U.S. Armenian community, while a small but growing minority of these (about 15\%) are involved in Armenian Studies.

3. Future. After 30 years, ABSA remains an informal and growing global network of over 700 diverse behavioral scientists and students. who meet at regional conventions. ABSA continues to offer a platform to unite Hye colleagues and students in the Republic of Armenia and Diaspora nations. 


\section{References}

1. Poghosian, G., Kalayjian, A., \& Takooshian, H. (Eds.) (1991). Directory of Sociologists in the Republic of Armenia. New York: ABSA.

2. Takooshian, H. (1987a). Armenian Behavioral Science Association inaugural meeting [A 90-minute VD]

3. Takooshian, H. (1987b). A census of psychologists in the Republic of Armenia, 1987. [A 90-minute VD]

4. Toth, V.A. (1987, August 31). Armenian Behavioral Science Association inaugural reception. [A 90-minute DVD]

5. Vardanian, G., Takooshian, H., \& Karakashian, M.A. (Eds.) (1991). Directory of Psychologists in the Republic of Armenia. (2 ed.). New York: ABSA. 